ELORE (ISSN 1456-3010), vol. $18-1 / 2011$.

Julkaisija: Suomen Kansantietouden Tutkijain Seura ry.

[http://www.elore.fi/arkisto/1_11/hammastrom.pdf]

KIRJA-ARVIO

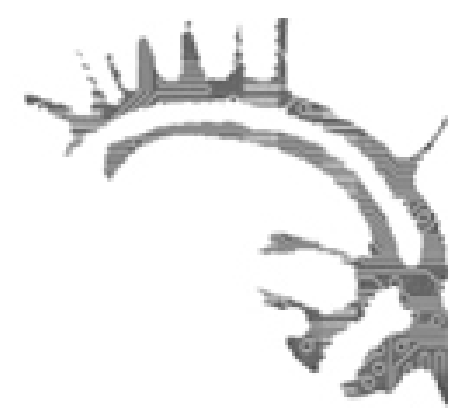

\title{
MONITIETEISTÄ LÄHETYSTYÖN TUTKIMUSTA
}

JALAGIN, SEIJA \&LÖYTTY, OLLI \& SALAKKA, MARKKU (toim.) 2010: Kaikille kansoille. Lähetystyö kulttuurien vuoropuheluna. Helsinki: SKS. 368 sivua.

\section{$\underline{\text { Kukka Hammarström }}$}

Kristillinen lähetystyö kertoo sekä uskontojen että kulttuurien kohtaamisesta. Se herättää samalla pohtimaan uskonnon ja kulttuurin rajoja sekä keskinäistä suhdetta. Kaikille kansoille. Lähetystyö kulttuurien vuoropubeluna esittelee monipuolisesti lähetystyön tutkimusta Suomessa. Teksteissä lähestytään uskontoa erityisesti kulttuurisena ja yhteiskunnallisena ilmiönä sekä yhtenä kansainvälisen vuorovaikutuksen muotona. Vaikka lähetystyön tavoitteet ovat ennen kaikkea hengellisiä, on toimintaympäristö erilaisilta henkisiltä ja materiaalisilta edellytyksiltään maallinen. Arkinen todellisuus lähetyskentällä on poikennut usein lähetysideologisten kirjoitusten ylevistä ajatuksista. Myös ajallisen ja paikallisen kontekstin huomioiminen on tärkeää lähetystyötä koskevassa tutkimuksessa.

Kristillisen uskon ja elämänohjeiden levittäminen vaikutti ja vaikuttaa edelleen vääjäämättä paikalliseen kulttuuriin ja maailmankuvaan. Kyse ei ole pelkästään uuden uskon omaksumisesta, vaan myös laajemmin erilaisten kulttuuristen vaikutteiden leviämisestä ja globaaleista verkostoista. Tässä on olennaista huomioida, että nämä vaikutukset ulottuvat myös lähettien kotimaahan.

\section{LÄHETYSTYÖSSÄ JA LÄHTEIDEN ÄÄRELLÄ}

Teoksessa on johdantoluvun lisäksi 13 artikkelia, jotka sijoittuvat kahden eri alaotsikon alle. Ensimmäisessä osassa, "Dialogin mahdollisuudet", käsitellään kulttuurien kohtaamista ja niiden välistä vuoropuhelua lähetysmission, ideologian ja opetustyön kautta. Toisessa osassa, "Vaativat vuorosanat", keskitytään itse tutkimusprosessiin ja tiedon tuottamiseen lähetystyötä koskevassa tutkimuksessa. Teoksessa ovat edustettuina niin historiantutkimus, antropologia ja kulttuurintutkimus, kasvatustiede kuin teologinen ja missiologinen tutkimuskin. Suuri osa teksteistä kiinnittyy historiantutkimukseen, 
mutta niissä näkyy myös vahva, nykypäivään johtava ajallinen sidos. Alueellisia kiinnekohtia ovat erityisesti Afrikassa ja Kiinassa tehty lähetystyö.

Ensimmäisen osan aloittaa Timo Vasko tarkastelemalla kristittyjen ja muslimien välisen vuoropuhelun historiallista taustaa, joka näyttäytyy myönteisempänä ja samalla hedelmällisempänä kuin ehkä yleisesti on ajateltu. Vasko käyttää yhtenä esimerkkinään kreikkalais-ortodoksisen kirkkoisän Johannes Damaskolaisen kirjoituksia yli tuhannen vuoden takaa. Kari Miettisen ja Katariina Lankisen teksteissä keskiössä ovat lähetysideologiat. Niissä pohditaan uskonnollisen ja kulttuurilähetyksen suhdetta: missä määrin lähetystyössä ovat painottuneet hengelliset, sivistykselliset ja toisaalta kulttuuriset tavoitteet? Miettisen ja Lankisen tapausesimerkeistä käy ilmi, että lähetysideologiat ja niiden kautta niin lähettien koulutus kuin toiminnan käytännöt kentällä ovat vaihdelleet riippuen lähetystyön kulloisestakin kotimaasta ja hengellisten suuntausten opillisista linjauksista riippuen. Ruut Lemmetyinen ja Markku Salakka liikkuvat kotikentällä Suomen tunnetuimman lähetyslaulun päähenkilön, Mustan Saaran matkassa. Lemmetyinen purkaa laulun taustaa ja sisällössä tapahtuneita muutoksia, joita se on saanut lähetysaatteen symbolina käydä läpi sopeutuessaan eri aikojen tarpeisiin ja maailmankuvaan. Salakan Musta Saara edustaa puolestaan vieraista kulttuureista esitettyä kuvaa suomalaisissa uskonnon oppikirjoissa 1970-80-luvuilla. Kirjan ensimmäisen osan päättää Päivi Hasun kuvaama esimerkki saksalaisen lähetystyön vaikutuksista avioitumisen käytäntöihin Kilimanjarolla 1900-luvun alkupuolella ja siitä, miten nämä vaikutukset ovat nähtävissä tänäkin päivänä.

Toisen osan ensimmäisessä tekstissä Seija Jalagin kuvaa lähteiden tulkinnan haasteita. Hän korostaa tutkittavien ilmiöiden tarkastelua osana laajempaa todellisuutta ja sen merkitysrakenteita. Jalaginin tapausesimerkki sijoittuu Japaniin suuntautuneeseen lähetystyöhön 1900-luvun alkuvuosikymmeninä. Pekka Lund tarkastelee psykohistorian näkökulmasta lähettien toimintaa ja valintoja lähetystyön vaikeissa tilanteissa 1920-luvun Kiinassa. Riika-Leena Juntunen pohtii osaltaan paikallisuuden tavoittamisen haasteita myös Kiinaan sijoittuvan tapaustutkimuksensa kautta. Hän kirjoittaa osuvasti: "[P]aikallisuus on mahdollista löytää ainoastaan ymmärtämällä kulttuurienvälisen vuorovaikutuksen molempien osapuolten taustat ja tiedostamalla kulttuurien kohtaamiseen liittyvät ongelmat.” (s. 254.)

Edellä kirjoitetun merkitys korostuu myös Markku Hokkasen parantamisen kulttuurihistoriaa käsittelevässä kirjoituksessa. Siinä Hokkanen pohtii erilaisten lähteiden rajoja ja mahdollisuuksia 1800-luvun lopun Afrikan Malawiin sijoittuvassa tutkimuksessaan. Leila Koivusen ja Jaana Skytän tutkimusesimerkkien kautta piirtyy kuva siitä, miten vieraita kulttuureja pyrittiin esittelemään 1900-luvun alun Suomessa. Koivunen kuvaa Kiinalais-afrikkalaisen lähetysnäyttelyn vaiheita ja samalla sitä koskevaa tutkimusprosessia itsessään. Skyttä puolestaan seuraa kirjoituksessaan niin lähetystyöntekijä ja etnografi Emil Liljebladin kuin hänen Ambomaalta keräämäänsä esine -ja tekstikokoelmansa vaiheita. Kirjan päättää luku, jossa Mika Vähäkangas esittelee missiologista eli lähetystieteellistä tutkimusta Suomessa. Vähäkankaan näkökulma avaa kirjan muiden esimerkkien valottamana laajemman kuvan lähetystyötä koskevan tutkimuksen kenttään. 


\section{KULTTUURI KOHTAAMISPINTANA JA KÄSITTEENÄ}

Lähetystyössä käytännön arki ja ideologiset käsitykset näyttävät olleen jatkuvan neuvottelun alaisena. Kentällä työskentelevien lähettien kaipaama tuki ja tarpeet eivät aina kohdanneet kotimaassa toimivan lähetysseurainstituution käsitysten kanssa. Parhaimmillaan työ kentällä oli kuitenkin antoisaa ja mahdollisti toimivan kanssakäymisen paikallisten kanssa. Tältä pohjalta moni lähetti saattoi myös omaksua laajan tuntemuksen paikallisesta kulttuurista ja kielistä. Toisinaan lähettien toimintakenttä rajoittui kuitenkin lähinnä lähetysaseman muurien sisäpuolelle, ja kontaktit paikallisiin saattoivat jäädä vähäisiksi.

Kuten kirjan teksteistä käy ilmi, lähetystyön kautta voidaan tarkastella kulttuurien kohtaamista monin eri tavoin. Toisaalta myös lähetystyöllä itsellään voidaan nähdä olevan oma kulttuurinsa ja merkitysjärjestelmänsä. Tässä tulee ottaa huomioon erilaisten lähetystyötä tekevien hengellisten suuntausten opilliset erot ja omat käsitykset, joilla on vaikutuksensa esimerkiksi tutkimuslähteissä näkyviin puhetapoihin. Kulttuurin käsite tulisi aina määritellä tutkimuskohtaisesti, niin tieteellisteoreettisten valintojen kuin tutkimusaineistonkin osalta.

Verrattuna kirjan muihin teksteihin Lundin käyttämä psykohistoriallinen tarkastelutapa tuntui vaikeimmin sisäistettävältä ja avautui kunnolla vasta toisella lukukerralla. Olen havainnut tämän aiemminkin kohdatessani psykohistoriallista näkökulmaa edustavia kirjoituksia. Melko raskaan teoreettisen analyysipaketin esittely ja soveltaminen näin lyhyessä tekstissä vaatii kenties asiaan perehtymättömältä lukijalta hieman tavallista enemmän.

Kaikille kansoille. Lähetystyö kulttuurien vuoropubeluna tarjoaa mielenkiintoisen ja virkistävän näkökulman laajaan ja moninaiseen kulttuurien kohtaamista koskevaan tutkimuskenttään ja samalla laajempaan yhteiskunnalliseen keskusteluun. Uskonnollisten kulttuuripiirien kohtaamispintoja tarkastelevana se on erittäin ajankohtainen. Tutkimusprosessia koskevat kirjoitukset kertovat puolestaan niistä valinnoista ja tulkinnoista, joita tutkija kohtaa ja tekee jatkuvasti työssään. Suosittelen kirjaa lämpimästi kaikille paitsi itse lähetystyön tutkimuksesta, myös laajemmin kulttuurien kohtaamisesta kiinnostuneille.

Filosofian maisteri Kukka Hammarström on folkloristiikan jatko-opiskelija Turun yliopistossa. 